When in Coorg, in two different years, during the months of January and February, we not unfrequently drove up to Mercara, the capital, a distance of ten miles from the place where we were staying. On the way thither we saw some trees in their winter condition with perfectly bare branches, others had the tender foliage of spring, some again were in all their summer glory, and some were clothed with the most brilliant autumnal tints; this was most probably due to the great variety in the species of trees in that district.

COSMOPOLITAN

\section{A Tracing Paper Screen}

As several inquiries have been made of me as to where the proper tracing paper can be obtained, perhaps I may be allowed to state that I got mine through Mr. George Smith, 26, Colebrooke Row, City Road, N., who was the first, I believe, to recommend the use of this valuable material.

Toppesfield Rectory, Halstead, Essex

ChaRles J. TAYLOR

\section{GEOFFREY NEVILL}

WE have to announce the comparatively early death of Mr. G. Nevill, which took place at Davos Platz, after a long and lingering illness, on February 1o. This removes from among us another of the scanty band of English conchologists, whose ranks, only a few days before, suffered a similar loss in Mr. J. Gwyn Jeffreys. Mr. Nevill's labours have been principally confined to India, where he was for many years one of the assistantsuperintendents under Dr. J. Anderson in the Indian Museum, Calcutta ; his work is, therefore, better known to those who have collected in the East and written on the molluscan fauna of that part of the world. For many years he was a constant correspondent and colleague of the writer's, who can testify to the large and varied knowledge Mr. Nevill possessed of the different forms. A very large number of species were sent him by Mr. Nevill from time to time, many of which still remain to be described. Mr. Nevill was the author of many papers on his favourite study, most of which are to be found in the Fournal of the Asiatic Society of Bengal; but perhaps his best and most useful work, particularly to those interested in distribution, was the "Hand List of Mollusca in the Indian Museum" (Part I, comprising the Pulmonata and Prosobranchia-Neurobranchia published in December, I878, and is remarkable for the accuracy with which the localities of the different species is given, and the collections from whence they were received. He also catalogued the Ampullariacea and Valvatida and Paludinidx). Unfortunately, the whole catalogue of the Gastropoda is incomplete, for his health failed him altogether in 188x. Yet he struggled on to the last with his task, even when unable to leave his room to go as usual to his office in the Museum, and was compelled eventually to give up his appointment and return to Europe. The entire arrangement of the Mollusca in the new Museum formed a part of his work when there, and it was well and admirably done. Almost his last work in the ficld was at Mentone, in $1878-79$, where, in the post Tertiary beds, he made a careful collection of the shells, particularly the smaller species, a list of which he published in the Zoological Society's Proceedings. Yet even so late as last summer, when hardly able to move from weakness and partial paralysis, he was getting together the land-shells to be obtained in the country around the Lago de Como.

Geoffrey Nevill was born at Holloway on October 5 , 1843; he was the second son of Mr. Wm. Nevill, F.G.S., who resided for many years at Langham Cottage, Godalming, a gentleman who made mineralogy his study, and whose collection of meteorites was well known. As is often the case, his son inherited kindred tastes, for, when quite a boy, his attention was directed to shell-collecting both in Germany and in England. Most of the English species in the Calcutta Museum originally formed a part of this collection, and bear labels from near his early home at Godalming. He received his education at Dr. H. D. Heatley's school at Brighton, and afterwards spent some time at Bonn in the house of Dr. F. H. Troschel, Professor of Zoology, and this no doubt confirmed his early taste for natural history and directed his future career.

He was never strong, so, after entering into mercantile life in his father's house, and his health breaking down, he was ordered abroad, and he proceeded to the Cape, the Mauritius, and Bourbon, where he collected largely, and formed a valuable and rich collection. Some of the results were described in joint papers by himself and his brother, Hugh Nevill, of the Ceylon Civil Service, He went on to the Seychelles Islands in 1868, where he remained some time, still further enriching his collection, and then went on to Calcutta. At this time an appointment offered itself in the New Museum, which he took and filled for many years. Here in Calcutta during this period a little band of workers in conchology were drawn together, most of whom were employed on the different surveys of the country. Season after season, on return from the field, the results of their labours in every part of India accumulated and were examined. Ferd. Stoliczka, one of the first to be removed, was one of the most ardent workers, and all benefited from his deep, more advanced knowledge of the subject.

The survivors will recall those pleasant intellectual gatherings when they hear of Geoffrey. Nevill's death, and future students and collectors of Indian Mollusca will appreciate the work he lived to perform, and which will render their work in the galleries of the museum in Calcutta more easy.

\section{REPORT OF THE COMMISSIONER OF EDUCA-} TION IN THE UNITED STATES FOR THE $Y E A R$ I $882-83^{1}$

I $\mathrm{T}$ is impossible to read the account which the United States Bureau of Education, in the opening pages of this Report for I882-83, gives of itself and of its labours, without being convinced of the value of the matter therein contained. A total of over 10,000 institutions of education of various kinds are in correspondence with, and supply information to, the department. An idea of the work also which falls to it may be formed from the fact that some questions addressed to it have necessitated months of research by several clerks, while the labour which its publications have entailed, as well as the value placed upon them, are shown by the fact that one of them was asked for by Io,00o persons of different addresses. Since all is voluntary, the Bureau claims to work the most complete system of the kind in existence. The wide compass of its survey is indicated by the very full account given, among other foreign intelligence, of the Report of the English Comnnission on Tecbnical Eduation. Besides itself circulating through the world 20,000 copies of its Report, the office is require dto print I8,000 copies more for the use of and distribution by, other members of the Government. Its library - where all the items of information which it is possible to collect, down to cuttings from newspapers, are gathered together and classified - is an immense work; and we can well believe that, "if this office were put in posscssion of a small sum annually for the purpose, it would make effective and useful displays at exhibitions, of Amcrican education.. the most unique feature of our national life."

The report of this education generally is far more satisfactory than in other years. There has been a general increase, first in the number of scholars, even in Maine where the population has become smaller, and in $\mathrm{Ncw}$ Jersey, New Hampshire, Connecticut, South Carolina, ' Washington Government Printing Office, 1884. 